\title{
Assessment of heavy metal contamination of soils and plants in and around open cast mines of Sukinda, India
}

\section{S.S. PANDA AND N.K. DHAL}

Article Chronicle :

Received:

25.11.2014;

Accepted :

15.05.2015

Key Words :

Mine dump,

Chromium, Soil,

Sukinda, Physico-

chemical

properties,

Phytoremediation
ABSTRACT : Mining activities generate huge amount of wastes with extremely high concentrations of heavy metal that have adverse effects on ecosystems and human health. Metal contamination extended several kilometers away from the mine sites probably by wind and water. Native vegetation was directly affected by the pollution. Hence, understanding the dynamic of metals in soil and plants is essential for ecosystem management and risk assessment. The present study was designed to assess the toxic metals viz., lead $(\mathrm{Pb})$, cadmium $(\mathrm{Cd})$, nickel $(\mathrm{Ni})$ and chromium $(\mathrm{Cr})$ present in the soil and plant samples of 18 plant species collected from nearby areas Sukinda chromite mining zone. Samples of soil and plants were collected from six different sites and were analyzed for $\mathrm{pH}, \mathrm{EC}, \mathrm{Cr}, \mathrm{Cd}$, $\mathrm{Pb}$ and $\mathrm{Ni}$ by $\mathrm{pH}$ meter, conductivity meter and atomic absorption spectrophotometer, respectively. Soil $\mathrm{pH}$ was slightly acidic in nature and varied from 5.5 to 6.4. Total heavy metal concentrations in soils were in the order of $\mathrm{Cr}>\mathrm{Ni}>\mathrm{Pb}>\mathrm{Cd}$. $\mathrm{Cr}$ and $\mathrm{Ni}$ exceed the critical limit value of WHO specified standard. Accumulation of metals in the plant species and in their organs varies, e.g. accumulation of heavy metal was higher in stem as compared to leaf. Ailanthus excelea Roxb. has highest capability for accumulating $\mathrm{Cr}$ in the shoot part as compared to other collected plants. The plants can ideally be used as the possible application in agricultural reconnaissance surveys, reclamation and revegetation of adversely affected mining environment.

How to CITE THIS ARTICLE : Panda, S.S. and Dhal, N.K. (2015). Assessment of heavy metal contamination of soils and plants in and around open cast mines of Sukinda, India. Asian J. Environ. Sci., 10(1): 76-82.
Author for correspondence :

\section{S.S. PANDA}

Department of

Environment and

Sustainability, CSIR-

Institute of Minerals and

Materials Technology,

BHUBANESWAR (ODISHA)

INDIA

Email: swati.sucharita8

@gmail.com

See end of the article for

Coopted authors' 